\title{
PENDIDIKAN KELUARGA BERBASIS GENDER PERSPEKTIF PENDIDIKAN
}

\section{AGAMA ISLAM}

\section{Akhmad Fadli}

STAI Taruna Surabaya

(fafifa05@gmail.com)

\begin{abstract}
Education is an activity carried out by humans where education has a broad scope. Education includes all experiences that exist in every human mind. Education is more pressing in terms of practices related to teaching and learning activities, besides that Education also focuses on thinking about education. Given the importance of parental role education in family education is also very important, where all children's knowledge and experience, both through vision, hearing, or behavior that comes from parents will influence the formation of children's personality, so parents should be able to educate her children, and the success of children in their future depends on how parents provide education. Likewise, the Gender Bias that exists in the family greatly affects the psychological condition of children in their lives in the future. Thus for the success of education in the family must be supported by Islamic religious education as a capital formation character that respects gender, and parents have a very important role in educating and directing their children, because if there is a gender bias in this family then this will greatly affect the mindset of their children in the future.
\end{abstract}

Keywords : Family Education, Gender and PAI 


\section{A. Pendahuluan}

Studi tentang gender bukan hanya sekedar sebuah upaya memahami perempuan atau laki-laki secara terpisah, tetapi bagaimana menempatkan keduanya dalam konteks sistem sosial yang integral. Konstruk sosial yang cenderung membedakan laki-laki dan perempuan, berdampak tidak hanya pada pengalaman yang berbeda antara keduanya, tetapi terjadi ketidaksetaraan dan ketidakadilan gender di bidang sosial, ekonomi, politik, dan hukum. Ketidaksetaraan dan ketidakadlilan gender ini menjadi problem pembangunan. Khususnya dalam menciptakan keadilan dan kesejahteraan di masyarakat.

Perbedaan yang berakar dari kelas sosial ekonomi, perbedaan etnis, perbedaan ras dan warna kulit maupun perbedaan agama ini dapat menimbulkan masalah ketidakadilan sosial di masyarakat, meskipun akhir-akhir ini tidak mengemuka lagi, namun perbedaan jenis kelamin (gender) masih merupakan persoalan yang hingga kini belum selesai. Fenomena ini bukan hanya terjadi di negara terbelakang dan negara berkembang, tetapi juga menjadi perjuangan perempuan di negara maju.

Membangun kesetaraan dan keadilan gender sulit dilakukan secara cepat, karena masih mengalami kendala-kendala yang bersumber dari legitimasi konstruksi budaya, interpretasi agama, dan kebijakan politik. Upaya mewujudkan kesetaraan dan keadilan gender dalam seluruh lini kehidupan perlu dilakukan secara terus menerus dan bertahap, baik dilakukan melalui kebijakan formal oleh Negara maupun kebijakan informal oleh tokoh masyarakat dan tokoh agama, keduanya menghadapi kendala-kendala sruktural maupun personal masing-masing individu telah memiliki sensitifitas gender, dan diikuti pula oleh kebijakan responsif gender di semua lembaga, instansi, organisasi pemerintah (goverment) maupun swasta (non goverment).

Perbedaan jenis kelamin sering digunakan masyarakat untuk mengkonstruk pembagian peran (kerja) laki-laki dan perempuan atas dasar perbedaan tersebut. Pada pembagian kerja gender atas jenis kelamin di mana laki-laki dan perempuan melakukan jenis pekerjaan yang berbeda. Pembagian ini dipertahankan serta dilakukan secara terus menerus. Pembagian kerja berdasarkan gender tidak menjadi masalah selama masing-masing pihak tidak merugikan atau dirugikan. Ketidakadilan gender dalam keluarga sering kali termanifestasi dalam berbagai bentuk, diantaranya adalah marginalisasi (peminggiran) perempuan, subordinasi (penomorduaan) perempuan, stereotipe (pelabelan negatif) terhadap 
perempuan, violence (kekerasan) terhadap perempuan serta beban kerja lebih banyak dan panjang (doble burden) ${ }^{1}$.

Dalam realitas kehidupan, pembedaan status sosial laki-laki dan perempuan di atas melahirkan perbedaan status sosial di masyarakat, di mana laki-laki lebih diunggulkan dari perempuan melalui konstruksi sosial. Pembagian peran gender yang diberikan pada laki-laki dan perempuan, sifat kegiatan, dan jenis pekerjaan yang berbeda, seolah-olah laki-laki hanya dapat melakukan jenis pekerjaan atau pendidikan tertentu, sebaliknya perempuan juga hanya dapat melakukan pekerjaan atau pendidikan tertentu pula. Pada umumnya masyarakat memandang tidak lazim jika peran tersebut ditukar atau diubah. Peran gender (gender role) tersebut kemudian diterima sebagai ketentuan sosial, bahkan oleh masyarakat diyakini sebagai kodrat. Pandangan demikian ini berdampak pada munculnya diskriminasi gender ${ }^{2}$.

Dampaknya, dengan adanya perbedaan gender maka guru memiliki peran yang sangat penting dalam mendidik dan mengarahkan anak-anaknya, karena apabila dalam suatu perbedaan terjadi bias gender, maka hal ini akan sangat berpengaruh pada pola pikir anakanaknya dimasa yang akan datang.

Dari sini sosok kyai sebagai bagian yang sangat penting dan panutan masyarakat diharapkan dapat memberikan pencerahan pada guru khususnya dan juga masyarakat luas terhadap pendidikan gender. Kyai menurut Geertz sebagai cultural broker, yang berfungsi menyampaikan informasi-informasi dari luar lingkungan yang dianggap baik dan membuang informasi yang dianggap kurang baik bagi masyarakat ${ }^{3}$. Kyai merupakan figur yang berperan sebagai penyaring informasi dalam memacu perubahan di dalam dunia pendidikan.

Oleh sebab itulah, tulisan ini akan berusaha dan berupaya membangun postulasi nilainilai gender serta pluralitas yang ada di dunia pendidikan, melalui dua pendekatan; pertama, berasal dari kerangkan fenomenologisme (baca; struktur kesadaran Kyai pesantren terhadap nilai tersebut). Kedua, konstruktivisme (baca; pola internalisasi, eksternalisasi dan objektivasi) terhadap para santri yang ada di lingkungan pondok pesantren. Tentu, sebagaimana judul di atas, kajian ini berbentuk studi kasus pendidikan sekolah berbasis gender perspektif para kyai. Kemudian, akan dilakukan proses generalisasi konsep (coding-

\footnotetext{
${ }^{1}$ Ahmad Mutholi'in, Bias Gender Dalam Pendidikan, (Jakarta: Paramadina, 2001).33

${ }^{2}$ Macam-macam diskriminilasi: a) Stereotipi gender (gender stereotype) yaitu pelabelan terhadap jenis kelamin laki-laki atau perempuan yang selalu berkonotasi negatif sehingga menimbulkan masalah. b) Subordinasi, yakni penempatan salah satu jenis kelamin lebih unggul dari jenis kelamin lainnya dari aspek status, peran dan relasi yang tidak setara.c) Marjinalisasi merupakan proses peminggiran secara sistemik, baik disengaja atau tidak, terhadap jenis kelamin tertentu dari mendapatkan akses dan manfaat dalam kehidupan akibat adanya stereotype dan subordinasi .d) Kekerasan (violence) berbasis gender yaitu kekerasan yang dilakukan oleh jenis kelamin berbeda yang disebabkan pandangan bias yang menempatkan

${ }^{3}$ Sukamto, Kepemimpinan Kyai Dalam Pesantren, (Jakarta: Pustaka LP3ES, 1999), 5.

36 | Akhmad Fadli, Pendidkan Keluarga Berbasis Gander Persepektif Pendidikan Agama

IslamP a g e
} 
concept), tujuanya agar sekolah bisa terlaksana dengan baik. Kajian ini, dalam pandangan penulis, setidaknya memiliki tiga kemanfaatan; pertama, dapat mengembalikan ingatan masyarakat akan nilai nilai sekolah. Kedua, menjadi counter-discourses terhadap cara pandang Barat yang mulai mengidentikkan sekolah dengan gerakan intoleransi di Indonesia. Ketiga, dapat menjadi sumber data untuk mendesain sistem pendidikan Islam yang sesuai dengan nalar berfikir keislaman di Indonesia.

\section{B. Urgensi Pendidikan Keluarga}

Keluarga adalah suatu institusi yang terbentuk karena suatu ikatan perkawinan antara sepasang suami istri untuk hidup bersama setia sekata, seiring dan setujuan, dalam membina mahligai rumah tangga untuk mencapai keluarga sakinah dalam lindungan dan ridha Allah SWT. Keluarga merupakan lembaga pendidikan yang bersifat informal, yaitu pendidikan yang tidak mempunyai program yang jelas dan resmi, selain itu keluarga juga merupakan lembaga yang bersifat kodrati, karena terdapatnya hubungan darah antara pendidik dan anak didiknya ${ }^{4}$. Di dalamnya selain ada ayah dan ibu juga ada anak yang menjadi tanggung jawab orang tua sebagaimana imam al-Ghozali bahwasanya anak adalah prioritas pertama bagi orang tua ${ }^{5}$. Keluarga merupakan persekutuan hidup terkecil dari masyarakat yang luas.

Keluarga merupakan ladang terbaik dalam penyemaian nilai-nilai agama. Pendidikan dan penanaman nilai-nilai agama harus diberikan kepada anak sedini mungkin, salah satunya melalui keluarga sebagai tempat pendidikan pertama yang dikenal oleh anak. Menurut Zuhairini, pendidikan keluarga merupakan lembaga pendidikan pertama, tempat anak pertama kalinya menerima pendidikan dan bimbingan dari orang tua atau anggota keluarga lainnya. Di dalam keluarga inilah tempat meletakkan dasar-dasar kepribadian anak didik pada usia yang masih muda, karena pada usia ini anak lebih peka terhadap pengaruh dari pendidikan (orang tua dan anggota lain) ${ }^{6}$.

\footnotetext{
${ }_{5}^{4}$ Suwarno, Pengantar Umum Pendidikan (Jakarta: Rineka Cipta, 1992), 66

${ }^{5}$ Mengenai tanggung jawab pendidikan anak terdapat perkataan yang berharga dari imam Abu al-Hamid alGhazali rahimahullah. Beliau berkata, "perlu diketahui bahwa metode untuk melatih/mendidik anak-anak termasuk urusan yang paling penting dan harus mendapat prioritas yang lebih dari urusan yang lainnya. Anak merupakan amanat di tangan kedua orang tuanya dan qalbunya yang masih bersih merupakan permata yang sangat berharga dan murni yang belum dibentuk dan diukir. Dia menerima apa pun yang diukirkan padanya dan menyerap apa pun yang ditanamkan padanya. Jika dia dibiasakan dan dididik untuk melakukan kebaikan, niscaya dia akan tumbuh menjadi baik dan menjadi orang yang bahagia di dunia dan akhirat. Dan setiap orang yang mendidiknya, baik itu orang tua maupun para pendidiknya yang lain akan turut memperoleh pahala sebagaimana sang anak memperoleh pahala atas amalan kebaikan yang dilakukannya. Sebaliknya, jika dibiasakan dengan keburukan serta ditelantarkan seperti hewan ternak, niscaya dia akan menjadi orang yang celaka dan binasa serta dosa yang diperbuatnya turut ditanggung oleh orang-orang yang berkewajiban mendidiknya" (Ihya Ulum al-Din 3/72).

${ }^{6}$ Zuhairini, dkk., Metodik Khusus Pendidikan Agama (Surabaya: Usaha Nasional, 1981), 38.

37 | Akhmad Fadli, Pendidkan Keluarga Berbasis Gander Persepektif Pendidikan Agama

IslamP a g e
} 
Anak dalam menuju kedewasaannya memerlukan bermacam-macam proses yang diperankan oleh bapak dan ibu dalam lingkungan keluarga. Keluarga merupakan wadah yang pertama dan dasar bagi perkembangan dan pertumbuhan anak. Pengalaman empiris membuktikan bahwa institusi lain di luar keluarga tidak dapat menggantikan seluruhnya peran lembaga bahkan pada institusi non keluarga. Kesadaran orang tua akan peran dan tanggung jawabnya selaku pendidik pertama dan utama dalam keluarga sangat diperlukan. Tanggung jawab orang tua terhadap anak tampil dalam bentuk yang bermacam-macam. Dalam hal ini, orang tua adalah pendidik pertama dan utama dalam keluarga sesuai sabda Rasulullah SAW:

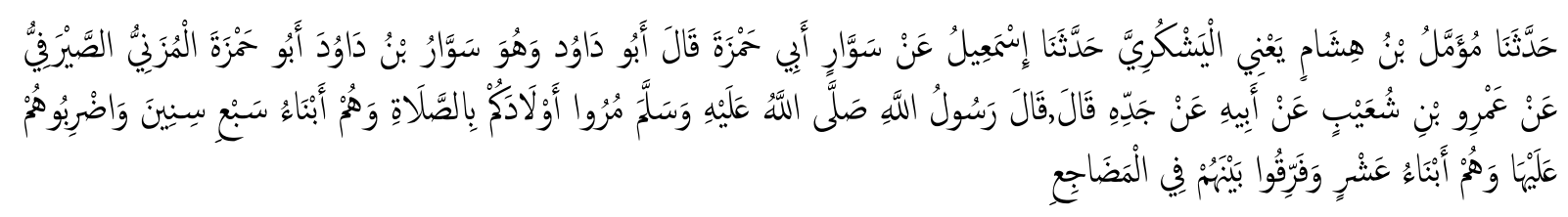

Artinya: "Berkata Mu'ammal ibn Hisyam Ya'ni al Asykuri, berkata Ismail dari Abi Hamzah, berkata Abu Dawud dan dia adalah sawwaru ibn Dawud Abu Hamzah Al Muzanni Al Shoirofi dari Amru ibn Syu'aib dari ayahnya dari kakeknya berkata, berkata Rasulullah SAW: Suruhlah anakmu melakukan sholat ketika berumur tujuh tahun. Dan pukullah mereka karena mereka meninggalkan sholat ketika berumur sepuluh tahun. Dan pisahlah mereka (anak laki-laki dan perempuan) dari tempat tidur." (H.R. Abu Dawud)

Sesuai dengan penjelasan hadits-hadits di atas, maka dapat kita ambil beberapa konsep pendidikan kontemporer yang sesuai dengan hadits-hadits tentang pendidikan keluarga. Di antaranya seperti penjelasan di bawah ini:

Menghormati dan bersikap santun kepada orang tua, diperintahkan oleh Allah dan Rasul-Nya. Rasa hormat dan santun tidak boleh berkurang kendatipun berbeda agama dengan orang tua itu (ibu-bapak). Agama Islam membedakan antara pergaulan dan akidah. Pergaulan berhubungan dengan sesama manusia, termasuk ibu bapak. Sedangkan akidah (iman) berhubungan dengan Allah SWT ${ }^{7}$.

Cara berbakti kepada kedua orang tua ibu-bapak di antaranya:

a. Bersikap sopan santun, berkata lemah lembut yang menyejukkan hati keduanya.

b. Perlihatkan muka yang jernih bila berhadapan dengan keduanya.

c. Berilah keperluan hidupnya yang layak.

d. Tempatkan keduanya pada tempat (rumah) yang layak.

Perhatian, sikap lemah lembut dan sopan santun lebih diutamakan. Sebab, materi, bukan segala-galanya. Walaupun kedua orang tua kaya raya, tetapi pemberian anaknya sangat tinggi nilainya dimata ibu-bapaknya. Orang tua tidak melihat harga barang yang diterimanya dan tidak pula melihat besar kecilnya. Keiklasan anaknya yang paling utama.

Perlu diketahui bahwa berbakti kepada ibu adalah lebih berlipat pahalanya dari kebaktian terhadap ayah. Begitulah maksud dari sebuah riwayat hadits. Hal ini disebabkan

\footnotetext{
${ }^{7}$ M. Ali Hasan, Mengamalkan Sunnah Rasulullah (Jakarta: Siraja, 2003), 180. 38 | Akhmad Fadli, Pendidkan Keluarga Berbasis Gander Persepektif Pendidikan Agama IslamP a g e
} 
karena sang ibu telah mangalami kesusahan dan kepayahan mengandung yang diikuti dengan sakitnya melahirkan anak, menyusui dan mengasuhnya hingga menjadi besar, dan seterusnya senantiasa memberikan penuh perhatian, belas kasih dan kasih sayang.

Sebagaimana seseorang itu wajib berbakti kepada kedua orang tua semasa mereka masih hidup, maka wajib pula berbakti kepada keduanya sesudah mereka mininggal dunia. Mendoakan orang yang sudah mati, dengan istighfar dan memohon ampunan bagi mereka, bersedekah bagi pihak mereka adalah terkandung faedah dan manfaat yang besar bagi orangorang yang sudah mati. Maka, hendaknya setiap orang tidak melalaikan perkara-perkara itu khususnya bagi kedua ibu-bapaknya, kemudian kepada keluarga dan orang-orang yang telah berbaik budi terhadap kita, dan sesudah itu kepada kaum muslimin sekalian ${ }^{8}$.

\section{Gender dalam Perspektif Pendidikan Islam}

Dalam kamus Inggris-Indonesia, disebutkan bahwa kata gender berasal dari bahasa Inggris gender yang berarti "jenis kelamin". 9 Arti ini rancu, karena dengan demikian gender disamakan dengan sex yang berarti “jenis kelamin”. Kamus Webster menyebutkan bahwa gender adalah "perbedaan yang tampak antara laki-laki dan perempuan dilihat dari segi nilai dan tingkah laku". ${ }^{10}$ Sedangkan dalam Women's Studies Encyclopedia dijelaskan bahwa gender adalah suatu konsep kultural yang berupaya membuat perbedaan dalam hal peran, perilaku, mentalitas, dan karakteristik emosional antara laki-laki dan perempuan yang berkembang dalam masyarakat. ${ }^{11}$ Hal ini senada dengan pendapat Mansour Fakih, bahwa gender adalah "suatu sifat yang melekat pada kaum laki-laki maupun perempuan yang dikonstruksi secara sosial maupun kultural". ${ }^{12}$

Mansour Fakih dalam buku yang lain mengadopsi pendapat Oakley yang mengatakan gender adalah behavioral differences antara laki-laki dan perempuan yang social constructed, yakni perbedaan yang bukan kodrat atau bukan ciptaan Tuhan, melainkan

\footnotetext{
${ }^{8}$ Imam Habib Abdullah Haddad, Nasehat Agama dan Wasiat Iman (Semarang: CV Toha Putra: 1993), 296.

${ }^{9}$ John M. Echols, Hassan Shadily, Kamus Inggris Indonesia (Jakarta: Gramedia, 1995), hlm. 265. (dalam jurnal Mahathir Muhammad Iqbal dan Studi Keislaman), vol. 15 (2015)

10 Victoria Neufeldt (ed.), hlm. Webster's New World Dictionary (New York: Webster's New World Clevenland, 1984), hlm. 561. Kata gender jika ditinjau secara terminologis merupakan kata serapan yang diambil dari bahasa Inggris, sedangkan jika dilihat posisinya dari segi struktur bahasa gramatikal adalah bentuk nomina (noun) yang menunjuk kepada arti jenis kelamin, sex atau disebut dengan al-jins dalam bahasa Arab. Hans Wehr, A Dictionary of Modern Written Arabic, cet. III (London: McDonald \& Evans Ltd., 1980), hlm. 141. Lihat pula Munir Ba'albakiy, Al-Maurid: Qāmūs Injilizīy Arabīy (Beirut: Dar al-'Ilm li al-Malaya in, 1985), hlm. 383. (dalam jurnal Mahathir Muhammad Iqbal dan Studi Keislaman), vol. 15 (2015).

${ }^{11}$ Nasaruddin Umar, Argumen Kesetaraan Jender Perspektif al-Qur'an (Jakarta: Paramadina: 2001), hlm. 3334. (dalam jurnal Mahathir Muhammad Iqbal dan Studi Keislaman), vol. 15 (2015).

${ }^{12}$ Mansour Fakih, Analisis Gender dan Transformasi Sosial (Yogyakarta: Pustaka Pelajar, 2003), hlm. 8. (dalam jurnal Mahathir Muhammad Iqbal dan Studi Keislaman), vol. 15 (2015).
}

39 | Akhmad Fadli, Pendidkan Keluarga Berbasis Gander Persepektif Pendidikan Agama

IslamP a g e 
diciptakan oleh baik kaum laki-laki maupun perempuan melalui proses sosial budaya yang panjang. ${ }^{13}$ Pandangan ini didukung oleh Zaitunah bahwa gender "merupakan sebuah konstruksi sosial yang bersifat relatif, tidak berlaku umum atau universal". ${ }^{14}$ Penggunaan kata seks lebih banyak berkonsentrasi kepada aspek biologi seseorang yang meliputi perbedaan komposisi kimia dan hormon dalam tubuh, anatomi fisik, reproduksi dan karakterisitik biologis lainnya. Sehingga kemudian dengan sadar atau tidak, aspek gender tersebut membawa konsekuensi logis bila ternyata berperan secara tidak adil.

Menurut sebagian besar tradisi agama dunia, perempuan diberi peran sekunder dan subordinat. Tetapi dalam tiga dasawarsa terakhir sebagian besar tradisi agama menarik sarjana feminis yang berpendapat bahwa bukan teks agama yang menjadi sebab masalah melainkan penafsirannya. Kaum feminis Kristen, Yahudi dan Islam meneliti kembali ayat suci mereka dan tiba pada kesimpulan bahwa agamanya menawarkan kemungkinan pembebasan dan perbaikan dalam posisi perempuan. Tetapi tradisi dan sejarah telah menumbangkan potensi ini dan menggunakan agama untuk menekan perempuan ${ }^{15}$. Memang ada sebuah penjelasan dalam Al-Qur'an tentang hubungan suami-istri yang tertulis pada surat an-Nisa' ayat 34, yang sebetulnya penuh dengan berbagai penafsiran

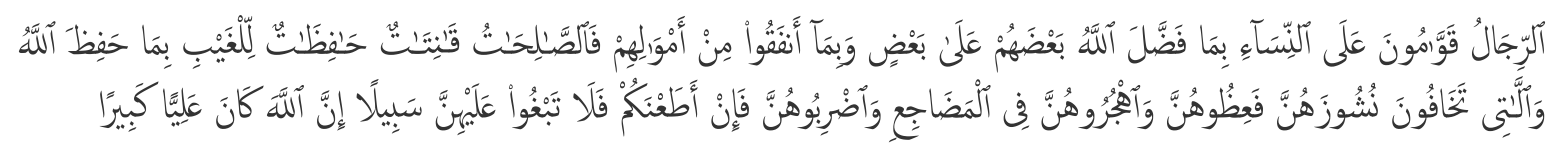

Artinya : Kaum laki-laki itu adalah pemimpin bagi kaum wanita, oleh karena Allah telah melebihkan sebahagian mereka (laki-laki) atas sebahagian yang lain (wanita), dan karena mereka (laki-laki) telah menafkahkan sebagian dari harta mereka. Sebab itu maka wanita yang saleh, ialah yang ta'at kepada Allah lagi memelihara diri ketika suaminya tidak ada, oleh karena Allah telah memelihara (mereka). Wanita-wanita yang kamu khawatirkan nusyuznya, maka nasehatilah mereka dan pisahkanlah mereka di tempat tidur mereka, dan pukullah mereka. Kemudian jika mereka menta'atimu, maka janganlah kamu mencari-cari jalan untuk menyusahkannya. Sesungguhnya Allah Maha Tinggi lagi Maha Besar $^{16}$.

Maka tidak sedikit mufassirin yang menjadikan ayat-ayat tersebut sebagai bentuk ketidak sesuaian perempuan dalam hal kesetaraan dengan laki-laki. Maka dari itu, selanjutnya norma-norma moral dan sosial dan hukum pun lebih banyak memberi hak kepada kaum laki-

\footnotetext{
${ }^{13}$ Mansour Fakih, et al., Membincang Feminisme: Diskursus Jender Perspektif Islam (Surabaya: Risalah Gusti, 1996), hlm. 46. (dalam jurnal Mahathir Muhammad Iqbal dan Studi Keislaman), vol. 15 (2015).

${ }^{14}$ Zaitunah, Tafsir Kebencian; Studi Bias Jender dalam Tafsir al-Qur'an (Yogyakarta: LKiS, 1993), hlm. 5. (dalam jurnal Mahathir Muhammad Iqbal dan Studi Keislaman), vol. 15 (2015).

${ }^{15}$ Julia Cleves Mosse, Gender dan Pembangunan, (Yogyakarta:Rifka Annisa' Women's Crisis Centre\&Pustaka Pelajar,1996), 85-86.

${ }^{16}$ Departemen Agama RI, Al Qur'an dan Terjemahnya

40 | Akhmad Fadli, Pendidkan Keluarga Berbasis Gander Persepektif Pendidikan Agama

IslamP a g e
} 
laki dari pada perempuan justru karena alasan bahwa laki-laki memang lebih bernilai secara publik dari perempuan. Dalam perkembangan patriarkhi dan seksisme ini sekarang telah menjadi istilah yang sangat popular dalam system kekeluargaan maupun social, politik dan keagamaan yang merendahkan bahkan menindas. ${ }^{17}$

Dalam perkembangan selanjutnya, maka harus ada usaha yang dijalankan oleh seseorang atau sekelompok orang untuk mempengaruhi tingkat hidup dan penghidupan yang lebih tinggi dalam arti mental ${ }^{18}$. Dengan demikian aka nada segala usaha orang dewasa dalam pergaulan dengan anak-anak untuk memimpin perkembangan jasmani dan rohaninya ke arah kedewasaan. Maka salah satu usaha yaitu dengan memberikan bimbingan, salah satunya dengan jalan pendidikan. Menurut D. Marimba, pendidikan ialah "bimbingan atau pimpinan secara sadar oleh pendidik terhadap perkembangan jasmani dan rohani anak didik menuju terbentuknya kepribadian yang utama ${ }^{19}$

Menurut Undang-undang Sistem Pendidikan Nasional No. 20 Tahun 2003 bab I Pasal I menjelaskan bahwa "pendidikan adalah usaha sadar dan terencana untuk mewujudkan suasana belajar dan proses pembelajaran agar peserta didik seacara aktif mengembangkan potensi dirinya untuk memiliki kekuatan spiritual keagamaan, pengendalian diri, kepribadian, kecerasan, akhlak mulia, serta ketrampilan yang diperlukan dirinya, masyarakat, bangsa dan negara $^{20}$. Oleh karena itu salah satu usaha agar mendapatkan pendidikan yang layak salah satunya dengan sekolah, karena sekolah merupakan wadah yang sudah teroganisir dengan baik.

Soleh Soegiyanto mengemukakan fungi - fungsi sekolah sebagai lembaga sosial, yaitu: 1) Sekolah berfungsi sebagai lembaga sosialisasi, membantu anak-anak dalam mempelajari cara-cara hidup di tempat mereka dilahirkan, 2) Sekolah berfungsi untuk mentransmisi dan mentranspormasikan kebudayaan, 3) Sekolah berfungsi menyeleksi murid untuk melajutkan pendidikan yang lebih tinggi. Pada kehidupan modern sekarang ini disamping pendidikan lainnya, kehadiran sekolah sebagai jalur pendidikan formal mempunyai peranan penting, karena tanpa lembaga sekolah, sumber-sumber dan kemampuan -kemampuan masyarakat yang sangat kompleks sulit kiranya untuk ditranspormasikan, atau disampaikan kepada generasi berikutnya secara efektif dan efisien.

\footnotetext{
${ }^{17}$ Buddy Munawwar Rahman, Islam Pluralis: wacana kesetaraan kaum beriman (Jakarta:PT Raja Grafindo Persada 2004). hlm. 539'531. dalam Jurnal Mahathir Muhammad Iqbal dan Studi Keislaman), Vol. 15 (2015)

${ }^{18}$ Sudirman N, Ilmu Pendidikan, (Bandung: CV. Remaja Karya, 1987), 4.

${ }^{19}$ D. Marimba, Pengantar Filsafat Pendidikan Islam, (Bandung: al-Ma"earif, 1989), 19

${ }^{20}$ UUSPN, UU RI No. 20 tahun 2003, Bab I, Pasal I No. 1

41 | Akhmad Fadli, Pendidkan Keluarga Berbasis Gander Persepektif Pendidikan Agama

IslamP a g e
} 
Mendidik merupakan wahana pendidik untuk konsisten terhadap apa yang dikatakannya. Satukanlah kata dengan perbuatan. Guru harus bisa memberikan warna tersendiri ketika proses pembelajaran demi menghadapi beberapa aspek utama perkembangan kejiwaan anak yaitu berkaitan dengan status sosial dan keragaman kemampuan kognisi yang akan mempengaruhi proses pendidikan di sekolah. Latar belakang sosial seperti keluarga, ekonomi masing-masing anak yang berbeda akan memberikan pengaruh pada prestasi anak di sekolah. Dengan kondisi perkembangan siswa pada masa ini maka proses pendidikan memerlukan kondisi kondusif agar perkembangan kemampuan kognitif, afektif dan psikomotorik siswa dapat mencapai tujuan yang diharapkan. Generasi muda adalah sebagai generasi penerus yang akan menggantikan estafet generasi orang tua, sudah barang tentu harus dibina dengan sungguh-sungguh agar mereka menjadi generasi penerus yang bertanggung jawab dan bermoral.

Oleh karena itu, terbentuknya suatu generasi tidak terlepas dengan adanya perbedaanperbedaan gender yang disebabkan oleh banyak hal, diantaranya adalah dibentuk, disosialisasikan, diperkuat, bahkan dikonstruksi secara sosial dan kultural melalui ajaran keagamaan maupun negara ${ }^{21}$. Melalui proses panjang sosialisasi gender tersebut akhirnya mengkristal menjadi dogma yang dianggap ketentuan Tuhan seolah-olah bersifat biologis yang tak bisa diubah lagi, sehingga perbedaan gender dianggap dan dipahami sebagai kodrat laki-laki dan kodrat perempuan.

Sehubungan dengan perspektif Islam tentang kesetaraan gender, al-Qur'an menegaskan bahwa (1) laki-laki dan perempuan sama-sama sebagai hamba, (2) laki-laki dan perempuan sama-sama sebagai khalifah, (3) laki-laki dan perempuan menerima perjanjian primordial, Adam dan Hawa terlibat secara aktif dalam drama kosmis, dan (5) laki-laki dan perempuan berpotensi meraih prestasi ${ }^{22}$.

Dalam kapasitas manusia sebagai hamba, tidak ada perbedaan antara laki-laki dan perempuan, karena masing-masing akan mendapat-kan penghargaan dari Tuhan sesuai dengan kadar pengabdiannya (QS. al-Nahl : 97). Keduanya mempunyai potensi dan peluang yang sama untuk menjadi hamba ideal (QS. al-Hujurât : 19). Kekhususan yang diperuntukkan kepada laki-laki seperti suami lebih tinggi di atas isteri, laki-laki pelindung perempuan, lakilaki memperoleh warisan lebih banyak dan diperkenankannya laki-laki berpoligami, tidak serta merta menyebabkan laki-laki menjadi hamba-hamba utama. Kelebihan-kelebihan

\footnotetext{
${ }^{21}$ Mansour Faqih, Analisis Jender\&Transformasi Sosial, 9.

${ }^{22} 2$ Nasaruddin Umar, Argumen Kesetaraan Gender, Perspektif al-Qur'ân. (Jakarta: Paramadina, 2001), hlm. 247-268.

42 | Akhmad Fadli, Pendidkan Keluarga Berbasis Gander Persepektif Pendidikan Agama IslamP a ge
} 
tersebut diberikan kepada laki-laki dalam kapasitasnya seba-gai anggota masyarakat yang memiliki peran publik dan sosial "lebih"23 ketika ayat-ayat al-Qur'ân tersebut diturunkan. Perbedaan gender sesungguhnya tidak menjadi masalah apabila tidak melahirkan ketidakadilan gender (gender inequalities). Namun kenyataannya, perbedaan gender telah melahirkan berbagai ketidakadilan, terutama bagi orang perempuan. Sehingga ada hak-hak bagi orang perempuan yang seharusnya bisa diterima menjadi tidak terpenuhi. Baik hak untuk berperan di dalam berpolitik, hak-hak dalam bidang pekerjaan serta hak dan kewajiban untuk memperoleh pengetahuan ${ }^{24}$. Padahal Nabi Muhammad mendemonstrasikan persamaan kedudukan laki-laki dan perempuan dalam aktivitas sosial, mulai dari kewirausahaan, politik sampai kepada peperangan ${ }^{25}$.

\section{Konsep Pendidikan Islam berbasis Gender}

\footnotetext{
${ }^{23}$ Laki-laki memperoleh otoritas persaksian satu berbanding dua dengan perempuan karena ketika itu fungsi dan peran publik berada dipundak laki-laki. Kekurangan "akal" dan "agama" (naqisat aql wa din) -sebagaimana dinyatakan dalam hadits - sehingga banyak kaum perempuan masuk neraka, tidak boleh dipahami Islam telah mendiskreditkan perempuan. Kata kekurangan akal dalam hadits tersebut tidak berarti perempuan secara potensial tidak mampu menyamai dan melampaui prestasi kreatifitas akal dan ibadah laki-laki. Demikian pula kekurangan agama tidak bisa dilekatkan kepada perempuan. Kekurangan agama -kalaulah boleh disebut demikian-terjadi pada diri perempuan karena memang hanya perempuanlah yang menjalani masa menstruasi. Laki-laki tidak menjalani siklus menstruasi sehingga ia tidak boleh meninggalkan ibadah-ibadah wajib tanpa alasan lain yang dapat dibenarkan. Peniadaan sejumlah ibadah dalam masa menstruasi adalah dispensasi khusus bagi menjalani proses menstruasi. Kekurangan akal (Nuqsan al-'aql) masih dapat diper-tanyakan lebih lanjut apa yang sesungguhnya dimaksud kata $a l$ - 'aql pada masa Nabi. Jika kekurangan akal dikaitkan dengan kualitas persaksian, sementara persaksian berhubungan dengan faktor budaya, maka bisa saja dipahami maksud kekurangan akal tersebut adalah keterbatasan penggunaan fungsi bagi perempuan karena adanya pembatasanpembatasan budaya, sehingga sifatnya bukan permanen atau alamiah. Demikian pula kekurangan agama yang dihubungkan dengan halangan perempuan untuk melakukan sejumlah ibadah dengan alasan "tidak bersih" memerlukan keterangan lebih lanjut karena halangan itu bukan kehendak perempuan, tetapi sesuatu yang alamiah yang mendapatkan dispensasi dari Tuhan, sehingga banyaknya perempuan dalam neraka dalam hadits mungkin saja karena populasi perempuan lebih besar dari pada laki-laki sehingga proporsional jika perempuan lebih banyak di dalam neraka daripada laki-laki.

${ }^{24}$ Marlinda Irwanti Pornomo, Keluarga Awal Kesetaraan dan Kemitraan lelaki \&Perempuan, (Banda Aceh: Biro Pemberdayaan Perempuan SETDAPROV NAD, 2002), 8-20.

${ }^{25}$ Nasaruddin Umar, "Metode Penelitian Berperspektif Gender tentang Literatur Islam", dalam Lathiful Khuluq, Peny. Rekonstruksi Metodologis Wacana Kesetaraan Gender dalam Islam. (Yogyakarta: PSW UIN Sunan Kalijaga ICIHEP Pustaka pelajar, 2002), hlm. 103. Fakta sejarah menunjukkan bahwa pada generasi sahabat terdapat 1232 sahabat perempuan yang beraktifitas di dunia ilmu. Pada masa Nabi Muhammad dan sahabatnya, banyak perempuan/isteri yang bekerja. Ada yang bekerja sebagai perias pengantin, seperti Um Satim binti Malhan, Shafiyah binti Huyay. Istri nabi yang lain, Zaynab binti Jahsyi aktif bekerja sebagai penyamak kulit binatang dan Raythah, istri Abdullah bin Mas'ud sangat aktif bekerja karena ekopnomi keluarganya tidak mencukupi. Periksa M. Quraish Shihab, "Kesetaraan Gender", dalam Umar, Argumen Kesetaraan, hlm. xxxv. Bandingkan Husien Muhammad, Fiqh Perempuan: Refleksi Kiai Atas Wacana Agama dan Gender. (Yogyakarta: LkiS, 2002), hlm. 137-145.
} 
Terbentuknya keluarga dengan sendirinya timbul karena adanya kewajiban untuk memelihara kehidupan bersama dalam keluarga. Orang tua adalah sumber pertama dan utama yang harus memberikan pendidikan kepada anak. Kehidupan dan nasib seorang anak sangat bergantung pada pendidikan dan pemeliharaan orang tua. Setiap anak memang terlahir dari rahim seorang ibu, tetapi itu bukan berarti bahwa hanya ibunya yang berkewajiban dan bertanggungjawab terhadap segala hal yang menyangkut pengasuhan anak. Di pundak ayah, memang letak kewajiban memenuhi kebutuhan materialnya, tetapi bukan berarti menjadikannya lepas tanggungjawab untuk mendidik anaknya. Dalam hal ini rosullullah SAW juga menegaskan bahwa kedua orang tualah yang sangat berperan "mewarnai" jiwa anak:

penjelasan itu ia dasarkan pada sebuah hadis Nabi yang diriwayatkan oleh Abu Hurairah ra.

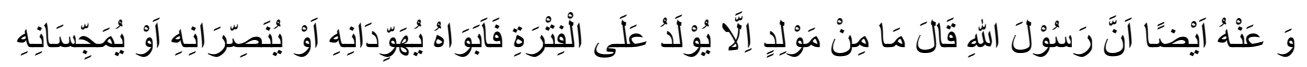

Dan diriwayatkan dari Abu Hurairah juga, bahwa sesungguhnya Rasulullah SAW bersabda: tidak ada seorang manusia yang terlahir kecuali dia terlahir atas fitrah (kesucian seperti tabula rasa, kertas yang belum ditulis apapun, masih putih). Maka kedua orang tuanyalah yang membuatnya menjadi Yahudi, Nasrani, ataupun Majusi "(H.R Ahmad, Thabranai dan Al-Baihaqi) ${ }^{26}$.

Hadis itu juga menunjukkan bahwa orang tua memiliki peran besar terhadap warna keagaman anaknya. Orang tua dapat memengaruhi keagamaan anaknya menjadi Yahudi, Nasrani ataupun Majusi. Orang tua yang dimaksud dalam hadis itu bisa berupa orang tua biologis, yakni ibu dan ayah kandungnya. karena keduanya sama-sama memiliki andil dalam menghadirkan keberadaan anak di dunia. Dan keduanyalah yang memberikan pengaruh yang kuat terhadapnya. Allah SWT juga telah memerintahkan dua orang tua untuk mendidik anakanak mereka dan mengembangkan tanggungjawab kepada mereka. Allah SWT berfirman:

"Hai orang-orang yang beriman peliharalah dirimu dan keluargamu dari api neraka yang bahan bakarnya manusia dan batu, sedang para penjaganya adalah malaikat yang kasar an keras, serta tidak pernah mendurhakai Allah terhadap apa yang diperintahkan-Nya kepada mereka serta selalu mengerjakan apa yang diperntahkan." (Q.S: at-Tahrim:6) ${ }^{27}$.

Dari firman Allah dan Sabda Rosullullah di atas, jelas bahwa yang bertanggungjawab dalam pendidikan anak dalam keluarga adalah orang tua (ayah dan ibu). Diakui secara sadar atau diterima dengan sepenuh hati atau tidak, hal itu adalah merupakan "fitrah" yang telah

\footnotetext{
${ }^{26}$ Ahmad bin Hanbal, Musnat Ahmad bin Hanbal, Juz 4, 24.

${ }^{27}$ Departemen Agama RI, Al Qur'an dan Terjemahnya, 951

44 | Akhmad Fadli, Pendidkan Keluarga Berbasis Gander Persepektif Pendidikan Agama

IslamP a g e
} 
dikodratkan Allah SWT kepada setiap orang tua. Mereka tidak bisa mengelakkan tanggungjawab itu karena merupakan amanah Allah SWT yang dibebankan kepada mereka ${ }^{28}$.

Kewajiban bagi keluarga dalam hal ini kedua orang tua adalah menyelenggarakan dan melaksanakan pendidikan kearah kedewasaan anak. Seperti yang telah dikatakan oleh Ki Hajar Dewantara, bahwa pendidikan keluarga adalah pendidikan yang baik bagi pendidikan sosial. Beliau mengatakan pendidikan keluarga merupakan pendidikan yang sempurna bagi pendidikan kecerdasan dan budi pekerti ketimbang pendidikan-pendidikan yang lain (selain keluarga $)^{29}$. Orang tua merupakan pendidik pemula bagi persoalan yang menyangkut diri anak dan juga tempat mengadu segala persoalannya. Pendidikan oleh orang tua berlangsung relatif panjang. Oleh karena itu, mereka sangat menentukan kepribadian anak. Tanggungjawab orang tua pada pendidikan anak berlangsung sejak anak masih dalam kandungan hingga tumbuh menjadi dewasa dan mampu mengembangkan diri pribadinya. Tanggung jawab tersebut meliputi beberapa aspek, yaitu aspek moral, aspek intelektual dan $\operatorname{aspek~sosial~}^{30}$.

Orang tua harus menanamkan nilai-nilai aqidah dan akhlaq yang benar untuk anakanaknya dengan memberi contoh nyata dalam perilaku. Rumah dengan segala aktivitas orang tua harus merupakan cermin bagi anak-anaknya. Rumah yang penuh kasih sayang, cinta antara sesama anggota, saling menghormati dan menghargai antara yang tua dan yang muda akan menegakkan keharmonisan dalam rumah tangga, serta menjadi tonggak keberhasilan dalam mendidik anak-anak. Seorang Ibu yang memberi tauladan dengan memberikan kasih sayang dan curahan perhatian kepada anak-anaknya, menghormati sang ayah, akan ditiru oleh putra-putrinya. Seorang ayah yang penuh kasih sayang terhadap anak-anaknya, tidak meremehkan ibu dan anak-anaknya, bahkan sangat menghargai mereka akan menimbulkan sikap senada yang terpatri dalam diri anak. Karena keluarga adalah salah satu elemen pokok pembangunan entitas-entitas pendidikan, menciptakan proses-proses naturalisasi sosial, membentuk kepribadian-kepribadian, serta memberi berbagai kebiasaan baik pada anak-anak yang terus bertahan selamanya. Dengan kata lain, keluarga merupakan benih awal penyusunan kematangan individu dan struktur kepribadian. Dalam banyak kasus, anak-anak mengikuti orang tua dalam berbagai kebiasaan dan prilaku. Jadi orang tua sangat diperluakan peran aktifnya dalam mendidik anak-anaknya ${ }^{31}$.

\footnotetext{
${ }_{28}^{28}$ Zakiyah Darajat, dkk, Ilmu Pendidikan Islam (Jakarta: Bumi Aksara, 1997), 35.

${ }_{30}^{29}$ Zainuddin, Seluk Beluk Pendidikan dari Al-Ghozali (Jakarta: Bumi Aksara, 1991), 71.

${ }^{30}$ Zainuddin, Seluk Beluk Pendidikan, 72-73.

31 Al-Qarasi, Baqir Syarif. (Seni Mendidik Islami. Jakarta: Pustaka Zahra, 2003). 46

45 | Akhmad Fadli, Pendidkan Keluarga Berbasis Gander Persepektif Pendidikan Agama

IslamP a g e
} 


\section{E. Urgensi Pendidikan Islam Bebasis Gender dalam Penididikan Keluarga}

Dengan menyimak betapa telah terjadi "tafsir yang melenceng" terhadap ajaran Islam tentang kesetaraan gender yang ditransformasi secara lestari melalui praktik pendidikan agama Islam yang berlangsung berabad-abad, maka perlu diadakan reorientasi, bahkan dekonstruksi terhadap struktur bangunan tafsir materi pendidikan agama Islam tersebut, dengan mengacu pada ajaran al-Qur'ân dan praktik teladan Nabi Muhammad saw.

Untuk itu diperlukan strategi pengarusutamaan kesetaraan gender melalui bahan ajar pendidikan agama Islam mengingat kehidupan mayoritas Muslim menunjukkan realitas aktual ketimpangan faktual sebagai berikut pertama, pola relasi laki-laki dan perempuan dalam masyarakat Muslim di Jawa misalnya, merupakan cerminan dari sistem pengetahuan tentang relasi laki-laki dan perempuan yang terserap dari budaya Jawa dan tafsir ajaran agama yang disosialisasikan melalui sentral pendidikan yaitu pesantren, madrasah dan sekolah $^{32}$. Kedua, beberapa penelitian menunjukkan bahwa lembaga pendidikan pesantren masih banyak diwarnai oleh gaya kepemimpinan paternalistik. Banyak pesantren yang menggunakan kitab 'Uqûd al-Lujjayn yang mengung-kapkan hak dan kewajiban suami istri dengan proporsi yang tidak imbang ${ }^{33}$.

Dengan datangnya Islam, posisi perempuan secara radikal terdifinisikan kembali. Islam melarang praktek penguburan bayi wanita dan memperbaiki hak-hak kelahiran wanit ${ }^{34}$.

Keadilan menurut Islam adalah terpenuhinya hak bagi yang memiliki secara sah, yang jika dilihat dari sudut pandang orang lain adalah kewajiban. Oleh karena itu, siapapun yang lebih banyak melakukan kewajiban atau yang memikul kewajiban lebih besar, dialah yang memiliki hak dibanding yang lain. Sementara ini, banyak anggapan bahwa beban suami atau beban produksi untuk mencari nafkah lebih berat dari beban istri (beban reproduksi: mengandung, melahirkan dan menyusui). Oleh karena tidak ada yang dapat dikatakan lebih berbobot antara hak dan kewajibannya, tetapi seimbang dan sejajar.

Dalam surat al-Isra' ayat 70 dinyatakan:

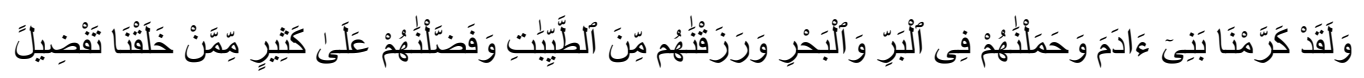

Artinya : "Dan sesungguhnya telah Kami mulyakan anak-anak Adam, Kami angkut mereka didaratan dan dilautan, Kami beri mereka rizki dari yang baik-baik dan Kami

\footnotetext{
${ }^{32}$ Periksa Umar, Argumen Kesetaraan Gender.

${ }^{33}$ Periksa Susilaningsih dan Agus M. Najib, ed. Kesetaraan Gender di Perguruan Tinggi Islam, (Yogyakarta: UIN Sunan Kalijogo dan McGill IISEP, 2004), hlm. 4.

${ }^{34}$ Haifaa, A.Jawad, Perlawanan Wanita Sebuah Pendekatan Otentik Religius, (Malang: Cendekia Paramulya, 2002), 15 .

46 | Akhmad Fadli, Pendidkan Keluarga Berbasis Gander Persepektif Pendidikan Agama

IslamP a g e
} 
lebihkan mereka dengan kelebihan yang sempurna atas kebanyakan makhluk yang telah kami ciptakan" 35 .

Dengan demikian menurut Engineer ${ }^{36}$, tidak diragukan lagi bahwa ada dorongan ke arah kesetaraan laki-laki dan perempuan dalam Al-Qur'an. Ada berbagai alasan untuk ini. Pertama, Al-Qur'an memberikan tempat yang sangat tinggi terhadap seluruh manusia yang mencakup laki-laki dan perempuan. Kedua, sebagai masalah norma, Al-Qur'an membela prinsip kesetaraan antara laki-laki dan perempuan. Perbedaan biologis tidak berarti ketidaksetaraan dalam status jenis kelamin. Fungsi-fungsi biologis harus dibedakan dari fungsi-fungsi sosial.

Yanggo $^{37}$ menjelaskan persamaan kedudukan perempuan dengan laki-laki menurut Al-Qur'an antara lain:

a. Dari segi pengabdian, Islam tidak membedakan antara laki-laki dan perempuan dalam pengabdian.perbedaan yang jadi ukurannya hanyalah ketaqwaannya.

b. Dari segi status kejadian, Al-Qur'an menerangkan bahwa perempuan dan laki-laki diciptakan Allah dalam derajat yang sama.

c. Dari segi mendapat godaan, di dalam Al-Qur'an disebutkan bahwa godaan dan rayuan iblis berlaku bagi laki-laki dan perempuan sebagaimana halnya Adam dan Hawa'.

d. Dari segi kemanusiaan, Al-Qur'an menolak pandangan yang membedakan laki-laki dan perempuan, khususnya dalam bidang kemanusiaan.

e. Dari segi pemilikan dan pengurusan harta, Al-Qur'an menghapuskan semua tradisi yang diberlakukan atas perempuan berupa larangan atau pembatasan hak untuk membelanjakan harta yang mereka miliki.

f. Dari segi warisan, Al-Qur'an memberikan hak waris kepada laki-laki dan perempuan.

g. Persamaan hukum tentang perceraian.

Senada dengan ungkapan Nasaruddin Umar, bahawasanyan laki-laki dan perempuan mempunyai hak yang sama ${ }^{38}$. Dalam hal kepemimpinan, Al-Qur'an menjelaskan bahwa perempuan dan laki-laki memiliki hak yang sama untuk menjadi pemimpin. Salah satu kisah

35 Departemen Agama RI, Al-Qur'an dan Terjemahnya, 435.

36 Asghar Ali Engineer, Islam dan Teologi Pembebasan, (Yogyakart: Pustaka Pelajar, 2000), 67.

37 Huzaemah Tahido Yanggo, Pandangan Islam tentang Gender, (Surabaya: Risalah Gusti, 1996), 152.

${ }^{38}$ Kedudukan anak laki-laki dan perempuan dalam keluarga menurut Al-Qur'an adalah sama. Bahkan semua laki-laki dan perempuan ditingkat manapun tidak berbeda. beberapa variabel yang dapat digunakan sebagai standar dalam menganalisa prinsip-prinsip kesetaraan gender dalam Al-Qur'an. Variabel tersebut adalah : 1) Laki-laki dan perempuan sama-sama sebagai hamba Allah, 2) Laki-laki dan perempuan sebagai khalifah (penguasa) di bumi, 3) Laki-laki dan perempuan menerima perjanjian primordial dengan Tuhannya, 4) Adam (sebagai simbol laki-laki) dan Hawa (sebagai simbol perempuan) terlibat secara aktif dalam dramis kosmis, 5)Laki-laki dan perempuan berpotensi meraih prestasi

47 | Akhmad Fadli, Pendidkan Keluarga Berbasis Gander Persepektif Pendidikan Agama

IslamP a g e 
yang sangat terkenal dalam Al-Qur'an adalah tentang seorang ratu (Al-Qur'an, an- Naml: ayat 22-23) yang digambarkan sebagai seorang perempuan yang menggunakan kekuasaan dengan sebaik-baiknya untuk membimbing rakyatnya agar patuh pada nabi Sulaiman. Ia adalah Ratu Saba', yang menjadi model peranan amat positif dari seorang perempuan yang menjadi kepala negara ${ }^{39}$.

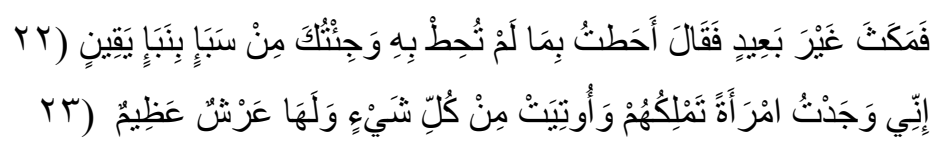

Artinya: Maka tidak lama kemudian (datanglah hud-hud), lalu ia berkata, "Aku telah mengetahui sesuatu yang belum engkau ketahui. Aku datang kepadamu dari negeri Saba' membawa suatu berita penting yang meyakinkan. Sesungguhnya aku menjumpai seorang wanita yang memerintah mereka, dan dia dianugerahi segala sesuatu serta mempunyai singgasana yang besar.

Sejarah kepemimpinan Aisyah - istri Nabi Muhammad SAW dalam dunia politik ikut memperkuat maksud dibalik cerita tentang Ratu saba' di atas. Puncak kepemimpinan Aisyah adalah ketika dalam perang jamal beliau memimpin sendiri pasukannya melawan Ali bin Abi Tholib, yang tiada lain adalah menantunya sendiri. Meskipun pada akhirnya ia dan pasukannya dikalahkan, tetapi ia berhasil menunjukkan pada umat bahwa seorang perempuan bisa menjadi pemimpin masyarakat.

Kemudian dalam hal perempuan yang bekerja, baik dalam lapangan ekonomi maupun social seperti halnya laki-laki menurut ajaran Islam, sebenarnya tidakalah menjadi masalah. Dalam Al-Qur'an, Hadits, maupun Fiqh yang merupakan sumber ajaran Islam tidak satupun ada penjelasan yang menafikan kerja dan profesi perempuan dalam segala sektor kehidupan, baik untuk kepentingan pribadi maupun kepentingan sosial ${ }^{40}$.

Serta dari segi peluang perempuan dalam mendapat pendidikan, terlalu banyak ayat al Qur'an dan hadits Nabi Saw. Yang berbicara tentang kewajiban belajar, baik kewajiban tersebut ditujukan kepada lelaki maupun perempuan. Wahyu pertama dari al Qur'an adalah perintah membaca atau belajar.

Para perempuan di zaman Rasul menyadari betul kewajiban ini, sehingga mereka memohon kepada Rasul Saw. Agar beliau bersedia menyisihkan waktu tertentu dan khusus untuk mereka dalam rangka menuntut ilmu pengetahuan. Permohonan tersebut tentu dikabulkan oleh Rasul SAW.

\footnotetext{
${ }^{39}$ Fatima Mernissi \& Riffat Hasan, Setara Dihadapan Allah, (Yogyakarta:LSPPA, 1996), 184

${ }^{40}$ Hussein Muhammad, Fiqih perempuan, (Yogyakarta; LKIS, 2001), 119.

48 | Akhmad Fadli, Pendidkan Keluarga Berbasis Gander Persepektif Pendidikan Agama

IslamP a g e
} 
Al Qur'an memberikan pujian kepada para Ulul Al Albab (intelektual) yang selalu berdzikir dan berfikir sekaligus memikirkan tentang telah diciptakannya langit dan bumi, pergantiannya siang dan malam, perputarannya matahari dan rembulan yang selalu aktif dan hanyalah Allah SWT. Yang Maha Pencipta. Dzikir dan pemikiran menyangkut hal tersebut akan mengantar manusia untuk mengetahui rahasia-rahasia alam raya, dan hal tersebut tidak lain dari pengetahuan.

Hal ini berarti bahwa kaum perempuan dapat berfikir, mempelajari dan kemudian mengamalkan apa yang mereka hayati dari dzikir kepada Allah Swt. serta apa yang mereka ketahui dari alam ini. Pengetahuan menyangkut alam raya tentunya berkaitan dengan berbagai disiplin ilmu, untuk dapat dipahami sesuai dengan keinginan dan kecenderungan masing-masing ${ }^{41}$.

Dengan demikian, Al-Qur'an yang merupakan kitab suci pemeluk agama Islam, sebenarnya menganugerahkan status yang setara antara laki-laki dan perempuan dalam pengertian normatif, namun juga mengakui superioritas laki-laki dalam konteks sosial tertentu. Namun para teolog yang menafsirkan ajaran Al-Qur'an tersebut telah mengabaikan konteks sosial yang dimaksud, sehingga menjadikan laki-laki sebagai makhluk superior. Pemahaman seperti ini kemudian mewarnai berbagai penafsiran terhadap ajaran yang terkait dengan hubungan laki-laki dan perempuan dalam kitab suci tersebut ${ }^{42}$

Dengan bahasa yang berbeda, Engineer mengungkapkan bahwa kitab suci Al-Qur'an itu bersifat normatif sekaligus pragmatis. Ajaran-ajarannya memiliki relevansi dengan zaman sekarang. Ajaran-ajaran yang demikian seharusnya tidak diperlakukan sebagai ajaran yang normatif. Ajaran ini harus dilihat dalam konteks di mana ajaran tersebut harus diterapkan ${ }^{43}$.

Jika demikian, menurut Rahmat $^{44}$, pemahaman keagamaan yang ada selama ini memberikan andil yang tidak kecil terhadap pelanggaran ide normatif Islam itu sendiri. Oleh karena itu jelas diperlukan kerendahan hati untuk mencermati ulang penafsiran yang dirasakan tidak mampu menjaga hak-hak kaum perempuan.

Pendapat tersebut didukung pula oleh Faqih ${ }^{45}$. Baginya, diperlukan kajian kritis guna mengakhiri bias dan dominasi dalam penafsiran agama. Maka diperlukan suatu proses kolektif yang mengkombinasikan studi, investigasi, analisis sosial, pendidikan, serta aksi

\footnotetext{
${ }^{41}$ Marlinda Irwanti Pornomo, Keluarga Awal Kesetaraan dan Kemitraan lelaki \&Perempuan,

${ }^{42}$ Ahmad Mutholi'in, Bias Gender Dalam Pendidikan, 45.

${ }^{43}$ Asghar Ali Engineer, Islam dan Teologi Pembebasan, 236.

${ }^{44}$ Imdadun Rahmat, Mengembalikan hak kaum perempuan (dalam Taswirul Afkar, Gerakan Perempuan Dalam Islam ),Jakarta:LAKPESDAM \&LTN NU,1999,hlm:1

${ }^{45}$ Mansour Faqih, Analisis Jender\&Transformasi Sosial, 134.
}

49 | Akhmad Fadli, Pendidkan Keluarga Berbasis Gander Persepektif Pendidikan Agama

IslamP a g e 
untuk membahas issu perempuan. Hal ini termasuk memberikan semangat dan kesempatan perlawanan kepada kaum perempuan guna mengembangkan tafsiran ajaran agama yang tidak bias terhadap laki-laki. Oleh sebab itu keluarga sangat penting dalam mengarahkan pengembangkan pribadi serta rasa kemasyarakatan yang ada pada diri anak, seperti melakukan komunikasi dan bergaul. Harmonisasi hubungan keluarga perlu dijaga agar anak merasa tentram dan damai dalam keluarga tersebut.

Keluarga merupakan salah satu pendidik yang memiliki arti penting bagi proses pendidikan anak. Makna tersebut yaitu:

1) Keluarga merupakan wadah pertama dan utama, anak diukir kepribadiannya, menemukan "aku" nya, mengenal kata-kata, tata nilai dan norma kehidupan, berkomunikasi dengan orang lain dan sebagainya, yang kesemuanya dimulai dari keluarga.

2) Dalam keluarga terdapat hubungan emosional yang kuat dan erat antar anggota keluarga, pendidikan berlangsung sepanjang waktu dan merupakan peletak pondasi pertama dalam membentuk kepribadian anak ${ }^{46}$.

Mengingat pentingnya keluarga yang demikian itu, maka Islam memandang keluarga bukan hanya persekutuan terkecil saja, tetapi lebih dari itu sebagai lembaga hidup manusia yang dapat memberi kemungkinan celaka dan bahagianya anggota keluarga tersebut baik di dunia maupun akherat.

Dilihat dari ajaran Islam, anak adalah amanat Allah. Dan amanah itu wajib di pertanggungjawabkan. Secara umum tanggung jawab itu adalah kewajiban orang tua untuk menyelenggarakan pendidikan bagi anak-anaknya dalam keluarga.

Peran keluarga bagi anak sangatlah besar, dan orang tua punya tanggung jawab untuk menuntun dan mengembangkan pribadi serta rasa kemasyarakatan yang ada pada diri anak, seperti melakukan komunikasi dan bergaul. Harmonisasi hubungan keluarga perlu dijaga agar anak merasa tentram dan damai dalam keluarga tersebut. Sebaliknya, jika terjadi disharmonisasi dalam keluarga, maka akan mempengaruhi jiwa anak dan menimbulkan keresahan batinnya Sedangkan untuk menciptakan suasana yang baik adalah dengan menciptakan terwujudnya saling pengertian, saling menghargai, saling mempercayai dan saling menyayangi diantara seluruh anggota keluarga Dengan demikian akan dapat dihindarkan dari berbagai masalah-masalah negatif yang akan mengganggu ketentraman keluarga tersebut ${ }^{47}$.

\footnotetext{
${ }^{46}$ Zainuddin,dkk, Seluk Bekuk Pendidikan dari Al-Ghozali, 71.

${ }^{47}$ Zakiyah Darajad, Ilmu Pendidikan Islam, 47.

50 | Akhmad Fadli, Pendidkan Keluarga Berbasis Gander Persepektif Pendidikan Agama

IslamP a ge
} 
Keluarga merupakan pusat pendidikan yang pertama dan utama. Di dalam keluarga inilah pertama kali anak mendapatkan didikan dan bimbingan, karena sebagian besar pendidikannya banyak diterima dari lingkungan keluarga. Sehingga pendidikannya pun banyak diterima dari lingkungan keluarga tersebut.

Hal yang demikian adalah wajar, karena keluarga khususnya orang tua adalah orang yang paling dekat dan paling bersahabat, bahkan semenjak anak masih ada dalam kandungan mereka sudah menjalin kasih sayang secara batin yang merupakan landasan utama dalam proses pendidikan.

Kunci pendidikan dalam keluarga sebenarnya terletak pada pendidikan rohani dalam arti pendidikan kalbu, lebih tegas lagi pendidikan agama bagi anak. Karena pendidikan agamalah yang berperan besar dalam membentuk pandangan hidup seseorang sebagai penanaman nilai-nilai yang kelak mewarnai perkembangan hidup selanjutnya. Bahkan dapat di katakan bahwa pendidikan agama dalam keluarga merupakan kunci bagi pendidikan secara keseluruhan.

\section{F. Kesimpulan}

Dari pemaparan mengenai pendidikan keluarga berperspektif Islam, dapat ditarik beberapa kesimpulan bahwa Pendidikan keluarga berbasis gender yang berperspektif Islam adalah pendidikan yang didasarkan pada tuntunan agama Islam tanpa membedakan status yang haus diterapkan dalam keluarga yang dimaksudkan untuk membentuk anak agar menjadi manusia yang beriman dan bertaqwa pada Tuhan Yang Maha Esa, serta berakhlak mulia yang mencakup etika, moral, budi pekerti, spiritual atau pemahaman dan pengalaman nilai-nilai keagamaan dalam kehidupan sehari-hari. Kewajiban mendidik anak bagi orang tua adalah suatu hal yang wajib untuk dilaksanakan. Karena anak adalah tanggung jawab yang diamanahkan oleh Allah untuk diberi pendidikan dan pengajaran. Orang tua harus bisa menjadi contoh serta panutan bagi putra-putrinya dalam hal ini menurut mereka peran ayah serta ibu untuk menjadi teladan bagi anak-anaknya sangatlah besar, karena ayah dan ibu adalah sosok model yang akan selalu ditiru dan dijadikan rujukan bagi putra-putrinya dalam menghadapi kehidupannya. Berbuat adil dan bijaksana terhadap semua anak adalah suatu hal yang seharusnya. Adil adalah sikap proposional yang tidak memprioritaskan yang satu dengan yang lain. Orang tua tidak boleh membeda-bedakan sikap terhadap anaknya. Orang tua tidak boleh mengabaikan anak yang lebih lemah (fisik/kemampuan) dan memprioritaskan yang lebih kuat (fisik ataupun prestasi), serta tidak boleh memberi perhatian yang lebih terhadap yang satu dibanding yang lain. Demikian pula dalam bidang pendidikan, setiap anak 51 | Akhmad Fadli, Pendidkan Keluarga Berbasis Gander Persepektif Pendidikan Agama IslamP a g e 
berhak untuk mendapatkan pendidikan yang sama dalam sebuah keluarga, maka keadilan orang tua dalam memberikan pendidikan kepada anak-anaknya adalah suatu hal harus dilakukan.

\section{DAFTAR PUSTAKA}

Al-Qarasi, Baqir Syarif. Seni Mendidik Islami. Jakarta: Pustaka Zahra, 2003

Asghar Ali Engineer, Islam dan Teologi Pembebasan, Yogyakart: Pustaka Pelajar, 2000

Darajat, Zakiyah, dkk, Ilmu Pendidikan Islam Jakarta: Bumi Aksara, 1997

Departemen Agama RI, Al Qur'an dan Terjemahnya

Echols, John M, Hassan Shadily, Kamus Inggris Indonesia, Jakarta: Gramedia, 1995

Fakih, Mansour, Analisis Gender dan Transformasi Sosial, Yogyakarta: Pustaka Pelajar,2003

Fatima Mernissi \& Riffat Hasan, Setara Dihadapan Allah, Yogyakarta:LSPPA, 1996

Hasan, M. Ali, Mengamalkan Sunnah Rasulullah, Jakarta: Siraja, 2003

Haddad, Imam Habib Abdullah, Nasehat Agama dan Wasiat Iman, Semarang: CV Toha Putra: 1993

Haifaa, A.Jawad, Perlawanan Wanita Sebuah Pendekatan Otentik Religius, Malang: Cendekia Paramulya, 2002

Hussein, Muhammad, Fiqih perempuan, Yogyakarta; LKIS, 2001

Huzaemah Tahido Yanggo, Pandangan Islam tentang Gender, Surabaya: Risalah Gusti, 1996

Imdadun Rahmat, Mengembalikan hak kaum perempuan (dalam Taswirul Afkar, Gerakan Perempuan Dalam Islam),Jakarta:LAKPESDAM \&LTN NU,1999

Marimba, D., Pengantar Filsafat Pendidikan Islam, Bandung: al-Maearif, 1989

Mutholi'in, Ahmad. Bias Gender Dalam Pendidikan. Jakarta: Paramadina, 2001.

Mosse, Julia Cleves, Gender dan Pembangunan, Yogyakarta:Rifka Annisa' Women's Crisis Centre\&Pustaka Pelajar, 1996

Pornomo, Marlinda Irwanti, Keluarga Awal Kesetaraan dan Kemitraan lelaki \&Perempuan, (Banda Aceh: Biro Pemberdayaan Perempuan SETDAPROV NAD, 2002

Rahman, Buddy Munawwar, Islam Pluralis: wacana kesetaraan kaum beriman Jakarta:PT Raja Grafindo Persada 2004). dalam Jurnal Mahathir Muhammad Iqbal dan Studi Keislaman

52 | Akhmad Fadli, Pendidkan Keluarga Berbasis Gander Persepektif Pendidikan Agama IslamP a g e 
Jurnal Keislaman, Vol 3, No 1

Sudirman N, Ilmu Pendidikan, Bandung: CV. Remaja Karya, 1987

Susilaningsih dan Agus M. Najib, ed. Kesetaraan Gender di Perguruan Tinggi Islam, Yogyakarta: UIN Sunan Kalijogo dan McGill IISEP, 2004

Sukamto, Kepemimpinan Kyai Dalam Pesantren, Jakarta: Pustaka LP3ES, 1999

Suwarno, Pengantar Umum Pendidikan Jakarta: Rineka Cipta, 1992

Zuhairini, dkk., Metodik Khusus Pendidikan Agama, Surabaya: Usaha Nasional, 1981

Umar, Nasaruddin, Argumen Kesetaraan Jender Perspektif al-Qur'an: Jakarta Paramadina, 2001

UUSPN, UU RI No. 20 tahun 2003, Bab I, Pasal I No. 1

Zaitunah,Tafsir Kebencian; Studi Bias Jender dalam Tafsir al-Qur'an, Yogyakarta: LKiS, 1993

Zainuddin, Seluk Beluk Pendidikan dari Al-Ghozali, Jakarta: Bumi Aksara, 1991 